\title{
FRACTIONATION OF PHOSPHORUS IN SOILS AMENDED WITH POULTRY MANURE CO-COMPOSTED WITH SUGARCANE AND CABBAGE WASTES
}

\author{
FRACIONAMENTO DE FÓSFORO EM SOLOS CORRIGIDOS COM ESTERCO DE \\ AVES CO-COMPOSTADO COM RESÍDUOS DE CANA DE AÇÚCAR E REPOLHO
}

\author{
Asma SALEEM $^{1}$; Muhammad IRSHAD ${ }^{1 *}$; A. Egrinya ENEJI² Amjad HASSAN $^{1}$; \\ Qaisar MAHMOOD ${ }^{1}$; Usman IRSHAD \\ 1. Department of Environmental Sciences, COMSATS Institute of Information Technology Abbottabad Pakistan. mirshad@ciit.net.pk; \\ 2. Department of Soil Science, University of Calabar, Nigeria
}

\begin{abstract}
Organic waste recycling is a viable option for reducing energy usage, volume of landfills, air and water pollution, greenhouse gas emissions and preserving natural resources for future use. Composting is an easy and natural bio-degradation process that converts organic wastes into available nutrients for plants. We studied the changes in phosphorus $(\mathrm{P})$ fractions in soils amended with poultry manure co-composted with sugarcane and cabbage wastes. The compost was applied to sandy clay and silt loam soils at 10 and $20 \mathrm{t} \mathrm{ha}^{-1}$. Soils were then incubated at room temperature for 8 weeks when mineralization was expected and analyzed for extractable $\mathrm{P}$ fractions. The $\mathrm{P}$ fractions in the soils varied in the order $\mathrm{HCl}-\mathrm{P}\left(\mathrm{Ca}+\mathrm{Mg}\right.$-bound) $>\mathrm{H}_{2} \mathrm{O}-\mathrm{P}$ (water soluble) $>\mathrm{NaHCO}_{3}-\mathrm{P}$ (readily plant-available $\left.\mathrm{P}\right)>\mathrm{NaOH}-\mathrm{P}(\mathrm{Fe}+\mathrm{Al}-$ bound) and the fractions increased significantly as compost application rates increased and decreased as the amount of sugarcane and cabbage wastes in the compost increased. Phosphorus was less concentrated in the compost containing CW than that containing SW and was higher in sandy clay than silty loam soil. The overall results showed that composting reduced the bio-availability of $\mathrm{P}$ from poultry litter and would be beneficial for optimizing $\mathrm{P}$ fertility in soil and minimizing losses to the environment.
\end{abstract} soil.

KEYWORDS: Co-composting. Poultry litter. Agro-waste. Phosphorus fractionation. Silt loam soil. Sandy clay

\section{INTRODUCTION}

Organic manures contain phosphorus $(\mathrm{P})$ and other essential plant nutrients, and crop production can benefit from land application of manures (HE et al., 2006). Broiler litter is a good source of phosphorus (MALONE, 1992) and most of the $\mathrm{P}(88-90 \%)$ in poultry litter is inorganic (SHARPLEY; MOYER, 2000). Phosphorus is an essential nutrient for plant growth and plays a vital role in energy storage, root development and early maturity of crops. It is usually applied to soil in the form of litter, plant residues and animal remains (BROGAN et al., 2001). Excessive application of manure $\mathrm{P}$ especially poultry litter to soils in the long term increases the $\mathrm{P}$ transfer to soil and/or surface water (SHARPLEY et al., 2007). Thus the use of poultry litter on agricultural lands with elevated $\mathrm{P}$ needs special management. One of the main environmental risks of poultry litter application is the imbalance of $\mathrm{N}$ and $\mathrm{P}$ in poultry manure, which is also not favorable for crop production (USDAERS, 2000). When poultry litter is applied to the soils in amounts based on the recommended $\mathrm{N}$ rates, $\mathrm{P}$ is often over-supplied, leading to $\mathrm{P}$ accumulation (SIMS et al., 2000). This $\mathrm{P}$ has the potential to leave the fields as soluble $\mathrm{P}$ in runoff water, leading in turn to the eutrophication of water bodies (SHARPLEY et al., 2007). Repeated applications of poultry litter can lead to $\mathrm{N}$ and $\mathrm{P}$ accumulation and to elevated levels of nutrients in the surface runoff and subsurface water (KINGERY et al., 1994). Moreover, the amount of $\mathrm{P}$ loss that would cause water quality problems is usually very low as compared to the amounts required by the crops or contained in the typical manure or fertilizer $\mathrm{P}$ applications. For example, lake water concentrations of $\mathrm{P}$ above $0.025 \mathrm{mg} \mathrm{\textrm {L } ^ { - 1 }}$ generally accelerate eutrophication. These values are an order of magnitude lower than $\mathrm{P}$ concentrations in soil solution critical for plant growth $\left(0.2\right.$ to $\left.0.3 \mathrm{mg} \mathrm{L}^{-1}\right)$, which illustrates the vulnerability to eutrophication of fresh waters. Bioavailability of applied $\mathrm{P}$ from organic manure is related not only to the total $\mathrm{P}$ content, but also to a particular $\mathrm{P}$ fraction present and their interaction with the soil matrix (TOTH et al., 2006). Studies on phosphorus fractionation are useful to obtain information about the potential availability and mobility of soil and sediment $P$.

Sequential chemical extraction methods have often been used to study $\mathrm{P}$ forms in soils and sediments (ADHAMI et al., 2013). The chemistry of 
the soil $\mathrm{P}$ is complex and soil $\mathrm{P}$ forms are often defined by the extractants that remove them from soil material in a sequential fractionation scheme. Several methods have been used to characterize different $\mathrm{P}$ forms in soils and animal manures (DOU et al., 2000; SHARPLEY; MOYER, 2000). These differences might be due to the distinct methods used in the assessment of $\mathrm{P}$ fractions (KOOPMANS et al., 2003), as well as the bird's diet, origin and management of the litters (MAGUIRE et al., 2006). Raw poultry litter application to soil could lead to serious environmental problems such as increased nutrient loss through leaching, erosion, and runoff from agricultural fields. The development of better management practices to optimize the application of manure $\mathrm{P}$ and to minimize the adverse environmental effects is of significant research interest. Fresh manure may quickly release $\mathrm{P}$ to soils, whereas more stable forms of organic matter (such as composts) generally act as long-term slow release sources of $\mathrm{P}$. The environmental problems associated with the raw poultry manure and fresh agricultural residues application could be mitigated by stabilizing its nutrient and organic matter contents by composting before application to the agricultural soils.

Composting is a controlled exothermic, microbial aerobic decomposition process in which organic wastes of different origins are transformed into relatively stable materials (FIALHO et al., 2010). Certain physical and chemical characteristics of the poultry manure are not adequate for composting and could limit the efficiency of the process: excess of moisture, low porosity, high $\mathrm{N}$ concentration for the organic $\mathrm{C}$, which gives a low $\mathrm{C} / \mathrm{N}$ ratio, and in some cases high $\mathrm{pH}$ values. The addition of bulking agents like sugarcane and cabbage wastes to poultry manure during composting would optimize key substrate properties (moisture, porosity, $\mathrm{C} / \mathrm{N}$ ratio, and $\mathrm{pH}$ ) and offer several environmental and economic benefits. Sugarcane and cabbage wastes are readily available in Abbottabad area of Pakistan. Information on the co-composting of these wastes with poultry litter, especially at optimal ratios during composting is scanty. This study evaluated short-term transformation of phosphorus in soils treated with poultry manure co-composted with sugarcane and cabbage wastes.

\section{MATERIAL AND METHODS}

Poultry litter (PL) was collected from poultry farms around Abbottabad, Pakistan while sugarcane waste $(\mathrm{SW})$ and cabbage waste $(\mathrm{CW})$ were collected from the local vegetable market. Poultry litter was co-composted with SW and CW in plastic bins $(>10 \mathrm{~L})$ and the bins were arranged inside a tiled roofed shed to protect from rainfall. The SW and CW were mixed with PL at the rates of 25, 33 and $50 \%$ in three replications and composted for $120 \mathrm{~d}$. Poultry litter without agro-waste $(0 \%)$ was set as a control treatment. During composting, treatments were occasionally moistened and aerated equally. Moisture in the manure was maintained at $30 \%$. During periodic sampling, the composting material was thoroughly mixed and the sampled portions were air dried, crushed, and sieved $(<0.5$ $\mathrm{mm}$ ) to ensure homogeneity.

The chemical properties $(\mathrm{EC}, \mathrm{pH}$, total $\mathrm{N}$, total $\mathrm{C}, \mathrm{C}$ : $\mathrm{N}$ etc) of samples were determined. Total carbon content was determined by dry combustion method (NELSON; SOMMERS, 1982). The $\mathrm{pH}$ of compost suspension with manure:water ratio of 1:5 was determined using a $\mathrm{pH}$ meter (HANNA HI 8520). This aqueous extract was obtained by mechanically shaking the samples with distilled water at a manure to water ratio of 1:5 (w/v) for $1 \mathrm{~h}$. The suspension was centrifuged and filtered through a Whatman 42. Electrical conductivity (EC) of the compost suspension was measured with an EC meter (4320 JENWAY). Kjeldahl $\mathrm{N}$ determination was performed according to APHA (1995). Carbon to $\mathrm{N}$ ratio was also calculated (Zhu et al., 2004). Samples weighing $0.25 \mathrm{~g}$ were digested in a mixture (1:3) of perchloric $\left(\mathrm{HClO}_{4}\right)$ and nitric $\left(\mathrm{HNO}_{3}\right)$ acids for the determination of total concentrations of macro- and micro-elements: potassium $(\mathrm{K})$, calcium $(\mathrm{Ca})$, magnesium $(\mathrm{Mg})$, sodium $(\mathrm{Na})$, copper $(\mathrm{Cu})$, iron $(\mathrm{Fe})$, manganese $(\mathrm{Mn})$, zinc $(\mathrm{Zn})$, using an atomic absorption spectrophotometer (AAS). Samples were digested with concentrated $\mathrm{HClO}_{4}$ by gradual heating over a hot plate for $1 \mathrm{~h}$. After drying, 20\% $\mathrm{HNO}_{3}$ was added and then heated again for $1 \mathrm{~h}$. The solution was diluted to $50 \mathrm{~mL}$ with deionized water and passed through a $0.22 \mu \mathrm{m}$ filter. Total $\mathrm{P}$ in the digest was determined by phosphomolybdate blue color method and absorbance was measured at $710 \mathrm{~nm}$. The chemical properties of the manure are given in Table 1.

\section{Soil incubation}

Two types of soils (silt loam and sandy clay) were sampled up to a depth of $20 \mathrm{~cm}$ from Abbottabad area. Soil samples were air-dried for 2 days and screened through a $2 \mathrm{~mm}$ sieve. The physico-chemical properties of soils were analyzed using standard procedures (Table 2). Two hundred and fifty grams of each soil sample was taken in a plastic bag and amended with co- 
composted material at four levels $(0,25,33$ and $50 \%$ ) by thoroughly mixing with the soils at 10 and $20 \mathrm{t} \mathrm{ha}^{-1}$ (based on 2 million $\mathrm{kg}$ soil per plow layer per ha.). The experiment was a $(2 \times 4 \times 2 \times 2)$ factorial (2 agro-wastes $\mathrm{x} 4$ blending ratios $\mathrm{x} 2$ soil types $\times 2$ rates of applications) resulting in 32 experimental units, arranged into a completely randomized design and replicated three times.

Table 1. Chemical composition of poultry litter (PL) co-composted with sugarcane (SW) and cabbage (CW) wastes at different levels.

\begin{tabular}{|c|c|c|c|c|c|c|c|c|}
\hline \multirow[t]{2}{*}{ Parameter } & \multirow[t]{2}{*}{ Unit } & \multicolumn{4}{|c|}{ SW (\%) } & \multicolumn{3}{|c|}{ CW (\%) } \\
\hline & & 0 & 25 & 33 & 50 & 25 & 33 & 50 \\
\hline Total C & $\mathrm{g} \mathrm{kg}^{-1}$ & 350 & 360 & 380 & 420 & 360 & 350 & 370 \\
\hline Total N & $\mathrm{g} \mathrm{kg}^{-1}$ & 25 & 21 & 19 & 15 & 18 & 15 & 11 \\
\hline Total P & $\mathrm{g} \mathrm{kg}^{-1}$ & 21.8 & 19.6 & 17.2 & 15.5 & 18.1 & 16.7 & 15.0 \\
\hline Total Ca & $\mathrm{mg} \mathrm{kg}^{-1}$ & 1274 & 1319 & 1334 & 1356 & 1322 & 1339 & 1350 \\
\hline Total Mg & $\mathrm{mg} \mathrm{kg}^{-1}$ & 437 & 450 & 457 & 464 & 445 & 449 & 463 \\
\hline Total K & $\mathrm{mg} \mathrm{kg}^{-1}$ & 800 & 811 & 822 & 829 & 809 & 815 & 825 \\
\hline Total Na & $\mathrm{mg} \mathrm{kg}^{-1}$ & 245 & 270 & 278 & 284 & 262 & 273 & 284 \\
\hline Total $\mathrm{Cu}$ & $\mathrm{mg} \mathrm{kg}^{-1}$ & 106 & 86 & 71 & 27 & 89 & 76 & 29 \\
\hline Total Fe & $\mathrm{mg} \mathrm{kg}^{-1}$ & 247 & 235 & 206 & 190 & 214 & 195 & 182 \\
\hline Total Mn & $\mathrm{mg} \mathrm{kg}^{-1}$ & 182 & 173 & 152 & 139 & 167 & 142 & 120 \\
\hline Total Zn & $\mathrm{mg} \mathrm{kg}^{-1}$ & 105 & 91 & 86 & 60 & 85 & 69 & 55 \\
\hline $\mathrm{EC}(1: 5)$ & $\mathrm{dS} \mathrm{m}^{-1}$ & 4.3 & 4.0 & 3.7 & 3.4 & 3.9 & 3.5 & 3.3 \\
\hline $\mathrm{pH}(1: 5)$ & & 8.9 & 8.5 & 8.3 & 8.1 & 8.3 & 8.1 & 7.9 \\
\hline
\end{tabular}

Table 2. Chemical composition of soils used for the study

\begin{tabular}{llll}
\hline Parameters & Unit & Silt loam & Sandy clay \\
\hline Total C & $\mathrm{g} \mathrm{kg}^{-1}$ & 26.9 & 31.4 \\
& & & \\
Total $\mathrm{N}$ & $\mathrm{mg} \mathrm{kg}^{-1}$ & 51.3 & 63.8 \\
Total $\mathrm{P}$ & $\mathrm{mg} \mathrm{kg}^{-1}$ & 59.3 & 75.8 \\
Total $\mathrm{Ca}$ & $\mathrm{mg} \mathrm{kg}^{-1}$ & 259.1 & 300.2 \\
Total $\mathrm{Mg}$ & $\mathrm{mg} \mathrm{kg}^{-1}$ & 125.2 & 151.6 \\
Total $\mathrm{K}$ & $\mathrm{mg} \mathrm{kg}^{-1}$ & 149.9 & 157.6 \\
Total $\mathrm{Na}$ & $\mathrm{mg} \mathrm{kg}^{-1}$ & 29.1 & 37.3 \\
Total $\mathrm{Cu}$ & $\mathrm{mg} \mathrm{kg}^{-1}$ & 48.3 & 61.7 \\
Total Fe & $\mathrm{mg} \mathrm{kg}^{-1}$ & 69.6 & 61.6 \\
Total $\mathrm{Mn}$ & $\mathrm{mg} \mathrm{kg}^{-1}$ & 61.5 & 75.5 \\
Total $\mathrm{Zn}$ & $\mathrm{mg} \mathrm{kg}^{-1}$ & 71.3 & 103.8 \\
Total Ni & $\mathrm{mg} \mathrm{kg}^{-1}$ & 2.3 & 2.7 \\
Total Cd & $\mathrm{mg} \mathrm{kg}^{-1}$ & 0.7 & 1.3 \\
EC $(1: 5)$ & $\mathrm{dS} \mathrm{m}$ & 0.6 & 0.9 \\
pH $(1: 5)$ & & 7.6 & 7.1 \\
& & & \\
\hline
\end{tabular}

The amended soils were incubated at room temperature $\left(25 \sim 30^{\circ} \mathrm{C}\right)$ in loosely covered plastic bags for eight weeks. Occasionally soil samples were moistened with distilled water and the water contents were maintained at approximately $20 \%$ (on air dry weight basis). After incubation, the soil samples were taken from each treatment, dried and analyzed for P.

Phosphorus fractionation was done by using modified sequential extraction procedure of Hedley et al. (1982), as described previously (ENEJI et al., 2003b; DOU et al., 2000; AJIBOYE et al., 2004). Incubated soil samples were fractionated into 
readily plant-available $\mathrm{P}$, labile inorganic $\mathrm{P}$ (another plant-available fraction), sesquioxide-associated inorganic $\mathrm{P}$ (Fe-oxide and Al-oxide) and $\mathrm{Ca}$ associated $\mathrm{P}$ by sequential extraction with deionized water, $0.5 \mathrm{M} \mathrm{NaHCO}{ }_{3}(\mathrm{pH} \quad 8.5), 0.1 \mathrm{M}$ $\mathrm{NaOH}$, and $1 \mathrm{M} \mathrm{HCl}$. The sequential extraction of inorganic P used in this study was as follows: $0.5 \mathrm{~g}$ sample of the soil-compost mixture $(0.5 \mathrm{~mm})$ was placed in a $50 \mathrm{~mL}$ centrifuge tube and sequentially extracted with $30 \mathrm{~mL}$ each of de-ionized water, $0.5 \mathrm{M} \mathrm{NaHCO} 3,0.1 \mathrm{M} \mathrm{NaOH}$ and $1 \mathrm{M} \mathrm{HCl}$. The extraction with each reagent was carried out in duplicate after $16 \mathrm{~h}$ of end-to-end shaking and then centrifuged at $10000 \mathrm{rpm}$ for $15 \mathrm{~min}$. Supernatants were filtered and the $\mathrm{P}$ contents determined calorimetrically using the molybdenum blue method (OLSEN; SOMMERS, 1982). The inorganic $\mathrm{P}$ in the extracts and digest were analyzed on a spectrophotometer at $710 \mathrm{~nm}$.

\section{Statistical analysis}

Data were statistically analyzed using analysis of variance with Stat-view. Mean separation was done using the least significant difference (LSD) at $\mathrm{P}<0.05$. Correlation was calculated to determine the relationships among $\mathrm{P}$ forms in the amended soils with the total amount of P.

\section{RESULTS AND DISCUSSION}

Phosphorus fractions in soils varied with composted manure amendments (Table 3-4). Most of the inorganic $\mathrm{P}(\mathrm{Pi})$ initially present in the composts was recovered as $\mathrm{Pi}$ during soil incubation. Higher application of poultry litter supplemented with sugarcane waste (SW) or cabbage waste $(\mathrm{CW})$ increased $\mathrm{P}$ concentrations in soil across fractions in the order of $\mathrm{HCl}-\mathrm{P}(\mathrm{Ca}+\mathrm{Mg}-$ bound) $>\mathrm{H}_{2} \mathrm{O}-\mathrm{P}>\mathrm{NaHCO}_{3}-\mathrm{P}$ (readily plantavailable $\mathrm{P}$ ) $>\mathrm{NaOH}-\mathrm{P}$ (Fe+Al-bound). However, compared to the control compost, the incorporation of SW and CW reduced the P concentrations in soil regardless of the $\mathrm{P}$ fractions. Poultry litter cocomposted with SW gave higher concentrations of $\mathrm{P}$ than with $\mathrm{CW}$. The sandy clay soil showed higher $\mathrm{P}$ concentration than the silt loam irrespective of manure treatments. Sharpley and Moyer (2000) reported differences in the amount and relative distribution of $\mathrm{P}$ forms in manure after composting process and material addition.

Table 3. Changes in $\mathrm{P}$ fractions $\left(\mathrm{mg} \mathrm{kg}^{-1}\right)$ in soil amended with poultry litter co-composted with sugarcane

\begin{tabular}{|c|c|c|c|c|c|c|c|}
\hline Soil & $\begin{array}{l}\text { Application } \\
\text { rate }\end{array}$ & SW & Organic $\mathrm{P}$ & $\mathrm{H}_{2} \mathrm{O}-\mathrm{P}$ & $\mathrm{NaHCO}_{3}-\mathrm{P}$ & $\mathrm{NaOH}-\mathrm{P}$ & $\mathrm{HCl}-\mathrm{P}$ \\
\hline \multirow[t]{5}{*}{ Silt loam } & $10 \mathrm{t} \mathrm{ha}^{-1}$ & 0 & 132.5 & 78.1 & 11.5 & 3.5 & 95.3 \\
\hline & & 25 & 125.3 & 73.5 & 9.5 & 2.6 & 89.0 \\
\hline & & 33 & 119.7 & 68.1 & 7.1 & 1.9 & 85.7 \\
\hline & & 50 & 111.3 & 61.1 & 5.3 & 1.3 & 80.5 \\
\hline & & $\begin{array}{l}\text { LSD } \\
(0.05)\end{array}$ & 3.5 & 2.4 & 0.7 & 0.3 & 3.7 \\
\hline \multirow[t]{5}{*}{ Sandy clay } & $10 \mathrm{t} \mathrm{ha}^{-1}$ & 0 & 151.4 & 87.2 & 15.1 & 5.3 & 103.6 \\
\hline & & 25 & 136.7 & 83.8 & 11.3 & 3.7 & 99.4 \\
\hline & & 33 & 125.3 & 78.5 & 9.7 & 2.5 & 96.3 \\
\hline & & 50 & 118.6 & 73.4 & 7.5 & 1.8 & 93.1 \\
\hline & & $\begin{array}{l}\text { LSD } \\
(0.05)\end{array}$ & 3.8 & 3.5 & 0.7 & 0.3 & 3.8 \\
\hline \multirow[t]{5}{*}{ Silt loam } & $20 \mathrm{t} \mathrm{ha}^{-1}$ & 0 & 148.2 & 91.3 & 17.3 & 7.1 & 107.3 \\
\hline & & 25 & 145.5 & 87.5 & 15.6 & 5.3 & 103.5 \\
\hline & & 33 & 139.7 & 83.7 & 11.8 & 3.7 & 98.7 \\
\hline & & 50 & 131.4 & 78.9 & 9.7 & 2.8 & 95.6 \\
\hline & & $\begin{array}{l}\text { LSD } \\
(0.05)\end{array}$ & 4.2 & 3.4 & 1.2 & 0.4 & 3.8 \\
\hline \multirow[t]{5}{*}{ Sandy clay } & $20 \mathrm{t} \mathrm{ha}^{-1}$ & 0 & 167.4 & 98.2 & 23.1 & 10.3 & 115.6 \\
\hline & & 25 & 163.7 & 95.8 & 19.3 & 8.7 & 111.4 \\
\hline & & 33 & 155.3 & 91.5 & 17.7 & 6.5 & 108.3 \\
\hline & & 50 & 151.6 & 87.4 & 15.5 & 3.9 & 105.1 \\
\hline & & LSD & 4.5 & 3.8 & 1.4 & 0.4 & 3.2 \\
\hline
\end{tabular}


Water extractable $\mathrm{P}$ concentrations were reduced by $21.8 \%$ in silt loam soil and $15.8 \%$ in sandy clay soil when the compost was applied at 10 $\mathrm{t} \mathrm{ha}^{-1}$ after supplementation with 50\% SW (Table 3). With the increase in compost application rate from 10 to $20 \mathrm{t} \mathrm{ha}^{-1}$, the water extractable $\mathrm{P}$ also increased. However, $\mathrm{H}_{2} \mathrm{O}-\mathrm{P}$ was reduced by $14.2 \%$ in silt loam soil and $11.2 \%$ in sandy clay soil when PL was supplemented with $50 \% \mathrm{SW}$. The PL composted with CW contained less $\mathrm{H}_{2} \mathrm{O}-\mathrm{P}$ than PL+ SW (Table 4). Poultry litter composted with 50\% $\mathrm{CW}$ reduced the water $\mathrm{P}$ by $32.1 \%$ in silt loam soil and $24.4 \%$ in sandy clay soil when applied at $10 \mathrm{t}$ $\mathrm{ha}^{-1}$; at $20 \mathrm{t} \mathrm{ha}^{-1}$ there was $30.7 \%$ reduction in $\mathrm{H}_{2} \mathrm{O}-\mathrm{P}$ in the silt loam and $25.5 \%$ reduction in the sandy clay soil. This observation confirmed that composting of agro-waste with PL would lower P enrichment in the runoff water.

Similarly the application of compost significantly reduced soil $\mathrm{NaHCO}_{3}-\mathrm{P}$ (Table 3-4). Across manure amendments, the $\mathrm{NaHCO}_{3}-\mathrm{P}$ fraction reduced by $17.3 \%$ in the soil treated with
$\mathrm{PL}+25 \% \mathrm{SW}, 38.2 \%$ in soil treated with PL $+33 \%$ SW, and $53.9 \%$ in soil treated with PL $+50 \%$ SW. The reduced concentrations of extractable $\mathrm{P}$ with increasing percentage of agro-waste were partially attributed to simple dilution phenomenon. Gagnon and Simard (2003) reported higher labile P in soil with the addition of composted poultry litter, vegetable residues and sheep manure than with the compost of beef and dairy cattle manure. The lower soil labile $\mathrm{P}$ found with dairy compost might be due to the lower total $\mathrm{P}$ content and higher $\mathrm{C}$ to $\mathrm{P}$ ratio as compared to other composts. The increase in the labile $\mathrm{P}$ in the amended soils was due to the $\mathrm{P}$ addition in the form of composted manure. Most of the $\mathrm{P}$ added with co-composts was recovered as $\mathrm{Pi}$ fractions in soils and preferentially in the labile fraction, which is considered easily available to crops and more vulnerable to the loss by leaching and surface runoff. Hosseinpur et al. (2012) reported that labile $\mathrm{P}$ had higher degree of biological availability.

Table 4. Changes in phosphorus fractions $\left(\mathrm{mg} \mathrm{kg}^{-1}\right)$ of soil amended with poultry litter co-composted with cabbage waste $(\mathrm{CW})$

\begin{tabular}{|c|c|c|c|c|c|c|c|}
\hline Soil & $\begin{array}{l}\text { Application } \\
\text { rate }\end{array}$ & $\mathrm{CW}$ & Organic $\mathrm{P}$ & $\mathrm{H}_{2} \mathrm{O}-\mathrm{P}$ & $\mathrm{NaHCO}_{3}-\mathrm{P}$ & $\mathrm{NaOH}-\mathrm{P}$ & HCl-P \\
\hline \multirow[t]{5}{*}{ Silt loam } & $10 \mathrm{t} \mathrm{ha}^{-1}$ & 0 & 132.5 & 78.1 & 11.5 & 3.5 & 95.3 \\
\hline & & 25 & 107.3 & 61.5 & 7.7 & 1.6 & 77.0 \\
\hline & & 33 & 103.7 & 57.3 & 5.9 & 1.0 & 75.7 \\
\hline & & 50 & 97.3 & 53.1 & 3.3 & 0.3 & 71.5 \\
\hline & & $\begin{array}{l}\text { LSD } \\
(0.05)\end{array}$ & 4.5 & 3.2 & 1.1 & 0.2 & 2.5 \\
\hline \multirow[t]{5}{*}{ Sandyclay } & $10 \mathrm{t} \mathrm{ha}^{-1}$ & 0 & 151.2 & 87.2 & 15.1 & 5.3 & 103.6 \\
\hline & & 25 & 123.7 & 72.8 & 9.5 & 2.3 & 89.4 \\
\hline & & 33 & 115.3 & 67.5 & 7.8 & 1.8 & 85.3 \\
\hline & & 50 & 110.6 & 61.4 & 5.5 & 1.5 & 79.1 \\
\hline & & $\begin{array}{l}\text { LSD } \\
(0.05)\end{array}$ & 4.3 & 2.5 & 0.5 & 0.2 & 2.7 \\
\hline \multirow[t]{5}{*}{ Silt loam } & $20 \mathrm{t} \mathrm{ha}^{-1}$ & 0 & 148.2 & 91.3 & 17.3 & 7.1 & 107.3 \\
\hline & & 25 & 127.3 & 73.8 & 10.7 & 2.6 & 89.0 \\
\hline & & 33 & 123.8 & 67.1 & 7.9 & 2.0 & 83.7 \\
\hline & & 50 & 117.3 & 63.1 & 7.3 & 1.3 & 77.5 \\
\hline & & $\begin{array}{l}\text { LSD } \\
(0.05)\end{array}$ & 4.6 & 2.8 & 0.6 & 0.3 & 3.2 \\
\hline \multirow{5}{*}{ Sandy clay } & $20 \mathrm{t} \mathrm{ha}^{-1}$ & 0 & 167.4 & 98.2 & 23.1 & 10.3 & 115.6 \\
\hline & & 25 & 143.7 & 83.8 & 13.5 & 5.7 & 97.4 \\
\hline & & 33 & 137.3 & 78.5 & 11.8 & 3.9 & 93.3 \\
\hline & & 50 & 130.6 & 73.4 & 9.5 & 3.3 & 87.1 \\
\hline & & $\begin{array}{l}\text { LSD } \\
(0.05)\end{array}$ & 4.7 & 2.7 & 0.6 & 0.3 & 3.2 \\
\hline
\end{tabular}

Changes in $\mathrm{HCl}$ and $\mathrm{NaOH}$ extractable $\mathrm{P}$ fractions were observed in PL amended soil with or without SW and CW treatments (Table 3-4). Higher contents of $\mathrm{P}$ fractions were found in control PL (without agrowaste) amended soils. The compost containing SW or $\mathrm{CW}$ had significantly less $\mathrm{HCl}-$ 
and $\mathrm{NaOH}-\mathrm{P}$ in soils. In the silt loam soil, the $\mathrm{NaOH}-\mathrm{P}$ was reduced from 3.5 to $2.6,1.9$ and 1.3 $\mathrm{mg} \mathrm{kg}^{-1}$ with 25,33 and $50 \% \mathrm{SW}$ in PL when amended at $10 \mathrm{t} \mathrm{ha}^{-1}$. In the sandy clay soil, the reductions were from 5.3 to $3.7,2.5$ and $1.8 \mathrm{mg} \mathrm{kg}^{-1}$, respectively. The NaOH-P was also reduced from 5.3 to $1.8,1.6$ and $0.3 \mathrm{mg} \mathrm{kg}^{-1}$ with 25,33 and $50 \%$ $\mathrm{CW}$ in PL when silt loam soil was amended at $10 \mathrm{t}$ $\mathrm{ha}^{-1}$; the reductions were from 7.1 to 2.6, 2.0 and 1.3 $\mathrm{mg} \mathrm{kg}^{-1}$, respectively in CW + PL amended silt loam soil at $20 \mathrm{t} \mathrm{ha}^{-1}$. Sandy clay soil released more P than silt loam soil. Hosseinpur et al. (2012) reported that non-occluded $\mathrm{P}$ represented $\mathrm{Fe}$ and $\mathrm{Al}$-bound $\mathrm{P}$, which is less available to plants than labile P. The increasing level of non-occluded $\mathrm{P}$ with manure application was consistent with previous reports (AKHTAR et al., 2005).

Slightly higher values of HCl-P were noted in the sandy clay than the silt loam soil. Soil amended with compost containing SW had higher P concentrations than that amended with compost containing $\mathrm{CW}$, but overall, the $\mathrm{HCl}-\mathrm{P}$ fraction in soils amended with control manure was the highest. This suggests that the addition of SW or CW affected the quality of organic matter and thus regulated the availability of $\mathrm{P}$ in the soil. Robinson and Sharpley (1996) reported high $\mathrm{Ca}$ in some animal manures enhanced the $\mathrm{PO}_{4}$ sorption capacity of soils by the formation of $\mathrm{Ca}-\mathrm{P}$ precipitates and complexes. Municipal solid waste compost do effectively supply $\mathrm{P}$ to the soil and soil $\mathrm{P}$ concentration increased with increasing application rates (HARGREAVES et al., 2008). Our results were also consistent with those of Hosseinpur et al. (2012) that manure application increased the calcium phosphate pool. Shen et al. (2004) reported that the dominant total inorganic $\mathrm{P}$ fraction in a calcareous soil during a long-term field trial was 69$71 \%$ of the total inorganic P. Wang et al. (1995) suggested that the greater concentration of acid inorganic $\mathrm{P}$ fraction in Grenada soil might be related to the level of free $\mathrm{CaCO}_{3}$, which favored the formation of $\mathrm{Ca}-\mathrm{P}$ fraction in the soil. Jalali; Ranjbar (2010) reported that reactions of $P$ added to the calcareous soils were quite rapid and watersoluble phosphate was converted to relatively less soluble compounds within a short time due to higher sorbing capacities of soils.

Total $\mathrm{P}$ contents varied with soil and ratio of composted manures. Total $\mathrm{P}$ concentrations were $111.3,119.7,125.3$ and $132.5 \mathrm{mg} \mathrm{kg}^{-1}$ when poultry litter was applied to the silt loam soil amended with $\mathrm{SW}$ at 50, 33, 25 and $0 \%$, respectively; the corresponding concentrations $\left(\mathrm{mg} \mathrm{kg}^{-1}\right)$ were 97.3 , 103.7, 107.3 and 112.5 when amended with $\mathrm{CW}$. In the sandy clay soil, total $\mathrm{P}$ values were 118,125 , $136,151 \mathrm{mg} \mathrm{kg}^{-1}$ when amended with compost containing SW and 110.6, 115.3, 123.7, $129.4 \mathrm{mg}$ $\mathrm{kg}^{-1}$ when amended with CW + PL at $10 \mathrm{t} \mathrm{ha}^{-1}$. When the silt loam soil was amended with $20 \mathrm{t} \mathrm{ha}^{-1}$, the $\mathrm{P}$ concentrations $\left(\mathrm{mg} \mathrm{kg}^{-1}\right)$ were $131.4,139.7$, 145.5 and 148.2 under 50, 33, 25 and $0 \% \mathrm{SW}+\mathrm{PL}$ compost and 117.3, 123.8, 127.3, 135.5 under CW + PL compost. For the sandy clay soil, the concentrations were 151.6, 155.3, 163.7, $167.4 \mathrm{mg}$ $\mathrm{kg}^{-1}$ under SW + PL compost at $20 \mathrm{t} \mathrm{ha}^{-1}$ and 130.6, 137.3, 143.7, 149.4, respectively under CW + PL. The differences in $\mathrm{P}$ release could be associated with soil type and compost mix. Gagnon et al. (2012) found more resin-P on P addition to slightly alkaline soil whereas $\mathrm{HCl}-\mathrm{P}$ and total $\mathrm{Pi}$ also increased after compost amendments. The soil $\mathrm{P}$ extracted by $\mathrm{NaHCO}_{3}$ and the total $\mathrm{Pi}$ increased with the time of incubation. A large part of total Pi increase was related to the increase in the $\mathrm{HCl}-\mathrm{P}$ fraction associated with $\mathrm{Ca}$. The sandy clay soil had more $\mathrm{P}$ than the silt loam soil.

Regression plots of $\mathrm{P}$ fractions $\left(\mathrm{g} \mathrm{kg}^{-1}\right)$ versus total $\mathrm{P}$ in the amended soils showed that the fractions were highly related to the total $\mathrm{P}$ in soils (Figure 1).

\section{Soil EC and pH}

The EC of the soils increased with the application of compost and that of sandy clay soil was $1.5 \mathrm{dS} \mathrm{m}^{-1}$ after amending with control compost compared with $2.3 \mathrm{dS} \mathrm{m} \mathrm{m}^{-1}$ when amended with compost containing SW (Table 5). The silt loam soil amended with compost containing SW at $0,25,33$ and $50 \%$ had EC values of 1.7, 1.9, 2.0 and $2.4 \mathrm{dS} \mathrm{m}^{-}$ ${ }^{1}$; when amended with compost containing $\mathrm{CW}$, the EC values were $1.6,1.5,1.9$ and $2.3 \mathrm{dS} \mathrm{m}^{-1}$, respectively. Eneji et al. (2003b) found the increases in EC level of soils was a function of source of manure applied and their salt contents. GallardoLara and Nogales (1987) showed an elevated salt content and EC after fertilization with composts. Acidic and alkaline soils showed an elevated EC, particularly when organic materials of varying nature were applied (GONZALEZ et al., 2010).

Increases in soil $\mathrm{pH}$ were noted following the manure amendment irrespective of the agrowaste treatments. The manure compost had slightly alkaline $\mathrm{pH}(>7)$ possibly on account of the high amount of basic cations it contained. Enhanced $\mathrm{pH}$ in soil after amendment with composted poultry manure has been reported (MANDEL et al., 2013). Roy and Kashem (2014) reported increases in soil $\mathrm{pH}$ incubated with different animal manures. 
Organic amendment increased the $\mathrm{pH}$ of contaminated soils (SABIR et al., 2008).
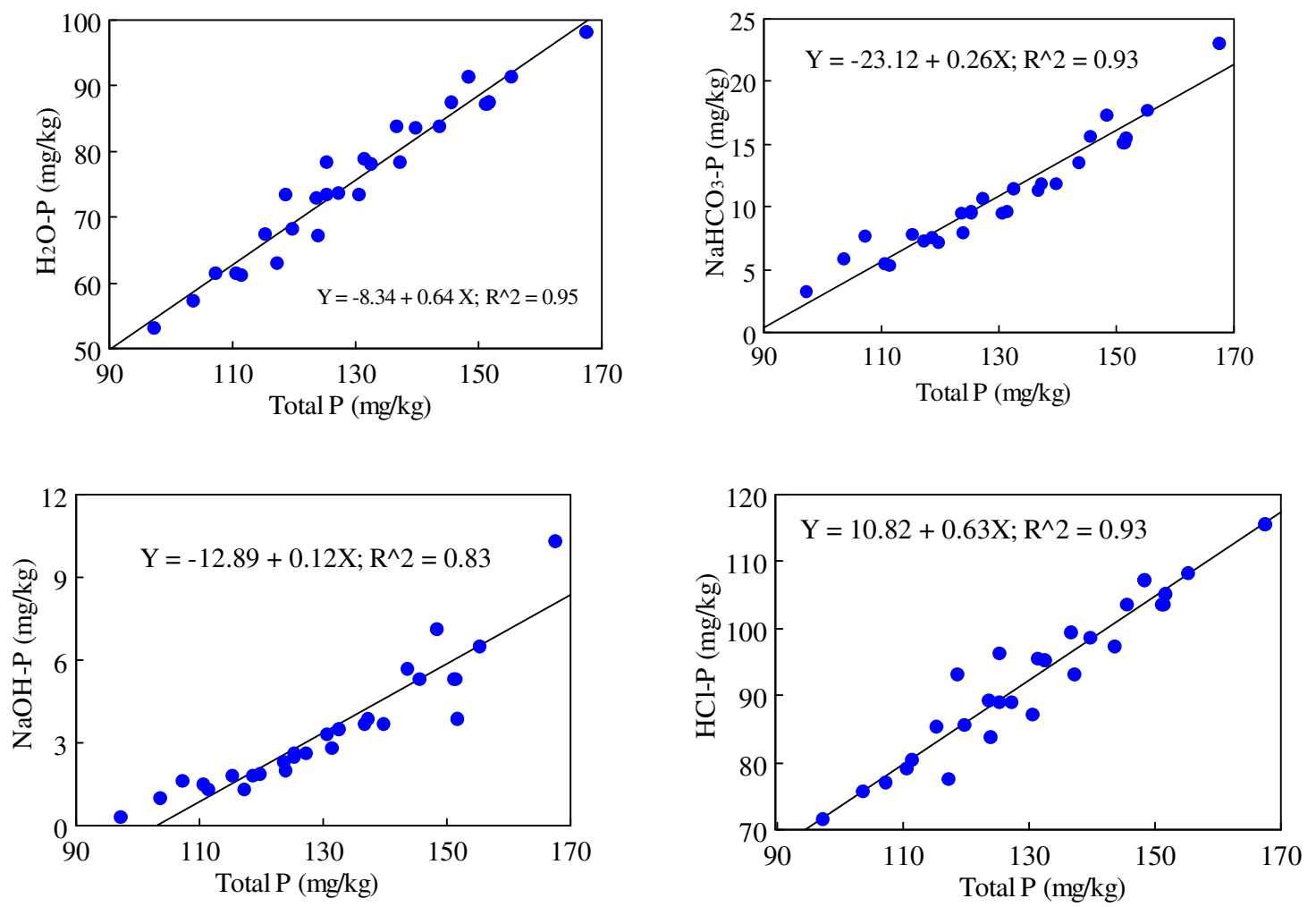

Figure 1. Regression plot between $P$ fractions $\left(\mathrm{g} \mathrm{kg}^{-1}\right)$ versus total $P$ in soils applied with composted poultry litter with agro-waste

Table 5. Changes in EC and pH of soil amended with poultry litter co-composted with sugarcane waste (SW) or cabbage waste $(\mathrm{CW})$

\begin{tabular}{llllll}
\hline Soil & $\begin{array}{l}\text { Agro-waste } \\
\text { in PL (\%) }\end{array}$ & $\begin{array}{l}\text { Soil applied with PL co- } \\
\text { composted SW } \\
\text { EC } \\
\mathrm{dS} \mathrm{m}^{-1}\end{array}$ & $\mathrm{pH}$ & \multicolumn{2}{l}{$\begin{array}{l}\text { Soil applied with PL co-composted } \\
\text { CW }\end{array}$} \\
\hline Silt loam & 0 & 1.7 & 7.3 & 1.6 & $\mathrm{pH}$ \\
& 25 & 1.9 & 7.5 & 1.5 & 7.2 \\
& 33 & 2.0 & 7.7 & 1.9 & 7.3 \\
& 50 & 2.4 & 7.9 & 2.3 & 7.6 \\
& LSD $(0.05)$ & 0.3 & 1.0 & 0.3 & 0.6 \\
\hline Sandy clay & 0 & 1.5 & 7.1 & 1.3 & 7.0 \\
& 25 & 1.8 & 7.3 & 1.5 & 7.2 \\
& 33 & 2.1 & 7.5 & 1.9 & 7.3 \\
& 50 & 2.3 & 7.7 & 2.3 & 7.5 \\
& LSD $(0.05)$ & 0.3 & 1.0 & 0.3 & 0.6 \\
\hline
\end{tabular}

\section{CONCLUSIONS}

The soil amendment with compost had a pronounced influence on the extractability of $\mathrm{P}$ fractions. The HCl-P was the predominant form of $\mathrm{P}$ in the amended soils and the fractions varied in the order $\mathrm{HCl}-\mathrm{P}>\mathrm{H}_{2} \mathrm{O}-\mathrm{P}>\mathrm{NaHCO}_{3}-\mathrm{P}>\mathrm{NaOH}-\mathrm{P}$. Generally the soil available $\mathrm{P}$ varied directly with the $\mathrm{P}$ in the applied compost.

The amounts of $\mathrm{NaHCO}_{3}-\mathrm{P}, \mathrm{HCl}-\mathrm{P}$ and $\mathrm{NaOH}-\mathrm{P}$ significantly increased whereas that of $\mathrm{H}_{2} \mathrm{O}-\mathrm{P}$ decreased with soil incubation. The sandy 
clay soil released more $\mathrm{P}$ than the silt loam soil. Phosphorus fractions decreased with increasing ratio of SW or CW in the compost.

The concentration of $\mathrm{P}$ in soils amended with compost containing $\mathrm{CW}$ was less than that in compost containing SW. Thus, the use of cocomposted manure rather than fresh manure in soils would be more beneficial in reducing P losses to the environment and regulation of its release for uptake by crops.

\section{ACKNOWLEDGEMENT}

The authors thankfully acknowledge the financial support of COMSATS Institute of Information Technology, Islamabad for $\mathrm{Ph}$. D research through the first author.

\begin{abstract}
Resumo: A reciclagem de resíduos orgânicos é uma opção viável para reduzir o uso de energia, o volume de aterros sanitários, a poluição do ar e da água, as emissões de gases de efeito estufa e a preservação dos recursos naturais para uso futuro. A compostagem é um processo fácil e natural de biodegradação que converte resíduos orgânicos em nutrientes disponíveis para plantas. Estudamos as alterações nas frações de fósforo (P) em solos alterados com esterco de aves de capoeira co-compostada com resíduos de cana de açúcar e repolho. O composto foi aplicado em solos arenosos, argilosos e limosos com 10 e 20 t ha-1. Os solos foram então incubados à temperatura ambiente durante 8 semanas quando a mineralização era esperada e analisada para as frações de $\mathrm{P}$ extraíveis. As frações de $\mathrm{P}$ nos solos variaram na ordem $\mathrm{HCl}-$ $\mathrm{P}(\mathrm{Ca}+\mathrm{Mg}$-bound) $>$ H2O-P (solúvel em água) $>$ NaHCO3-P $($ P prontamente disponível para a planta $)>\mathrm{NaOH}-\mathrm{P}(\mathrm{Fe}+$ Al-bound) e as frações aumentaram significativamente à medida que as taxas de aplicação de composto aumentaram e diminuíram à medida que aumentou a quantidade de resíduos de cana de açúcar e de repolho na compostagem. O fósforo estava menos concentrado no composto contendo $\mathrm{CW}$ do que o que continha SW e era mais alto em argila arenosa do que o solo limoso. Os resultados globais mostraram que a compostagem reduziu a biodisponibilidade do $\mathrm{P}$ vindo do lixo de aves de capoeira e seria benéfica para otimizar a fertilidade do $\mathrm{P}$ no solo e minimizar as perdas para o meio ambiente.
\end{abstract}

KEYWORDS: Co-compostagem. Lixo de aves de capoeira. Agro-resíduos. Fracionamento de fósforo. Solo limoso. Solo de argila arenosa.

\title{
REFERENCES
}

ADHAMI, E.; OWLIAIE, H. R.; MOLAVI, R.; REZAEIRASHTI, M.; ESFANDBOD, M. Effects of soil properties on phosphorus fractions in subtropical soils of Iran. Journal of Soil Science and Plant Nutrition, v. 13, n. 1, p. 11-21, 2013. https://doi.org/10.4067/s0718-95162013005000002

AJIBOYE, B.; AKINRREMI, O. O.; RACZ, G. J. Laboratory characterization of phosphorus in fresh and ovendried organic amendments. Journal of Environmental Quality, v. 33, p. 1062-1069, 2004.

https://doi.org/10.2134/jeq2004.1062

AOAC. 1995. Official Methods of Analysis, Association of Official Analytical Chemists, 15th ed. Washington, D.C.

AKHTAR, M., MCCALLISTER, D., FRANCIS, D.; SCHEPERS, J. Manure source effects on soil phosphorus fractions and their distribution. Soil Science Society of America Journal, v. 170, p. 183-190, 2005. https://doi.org/10.1097/00010694-200503000-00004

BROGAN, J.; CROWE, M.; CARTY, G. Developing a National Phosphorus Balance for Agriculture in Ireland. Environmental Protection Agency, Wexford, Ireland, 2001.

DOU, Z.; TOTH, J. D.; GALLIGAN, D. T.; RAMBERG, JR. C. F.; FERGUSON, J. D. Laboratory procedure for characterizing manure phosphorus. Journal of Environmental Quality, v. 29, p. 508-514, 2000. https://doi.org/10.2134/jeq2000.00472425002900020019x https://doi.org/10.2134/jeq2000.292508x 
ENEJI, A.E.; HONNA, T., YAMAMOTO, S., MASUDA, T., ENDO, T., AND IRSHAD, M. The relationship between total and available heavy metals in composted manure. Journal of Sustainable Agriculture, v. 23, p. 125-134, 2003b. https://doi.org/10.1300/J064v23n01_09

ENEJI, A. E.; HONNA, T.; YAMAMOTO, S.; MASUDA, T.; IRSHAD, M. 2003b. Changes in humic substances and phosphorus fractions during composting. Communications in Soil Science and Plant Analysis, v. 34, n 15-16, p. 2303-2314, 2003a. https://doi.org/10.1081/CSS-120024065

FIALHO, L.; SILVA, W.; MILORI, D.; SIMÕES, M.; MARTIN, L. Characterization of organic matter from composting of different residues by physicochemical and spectroscopic methods. Bioresource Technology, v. 101, n. 6, p. 1927-1934, 2010. https://doi.org/10.1016/j.biortech.2009.10.039

GAGNON, B., SIMARD, R. R. Soil P fractions as affected by on-farm composts in a controlled incubation study. Canadian Journal of Soil Science, v. 83, 223-226, 2003. https://doi.org/10.4141/S02-025

GALLARDO-LARA, F.; NOGALES, R. Effect of the application of town refuse compost on the soil-plant system: A review. Biological Wastes, 19, p. 35-62, 1987. https://doi.org/10.1016/0269-7483(87)90035-8

GONZALEZ, M.; GOMEZ, E.; COMESE, R.; QUESADA, M.; CONTI, M. Influence of organic amendments on soil quality potential indicators in an urban horticultural system. Bioresource Technology, v. 101, p. 88978901, 2010. https://doi.org/10.1016/j.biortech.2010.06.095

GOLUEKE, C. G. Composting - A Study of the Process and its Principles. Rodale Press, Emmaus, PA. 1973.

HARGREAVES, J. C.; ADL, M. S.; WARMAN, P. R. A review of the use of composted municipal solid waste in agriculture. Agriculture, Ecosystems and Environment, v. 123, p. 1-14, 2008.

https://doi.org/10.1016/j.agee.2007.07.004

HE, Z., GRIFFIN, T. S. AND HONEYCUTT, C. W. Soil phosphorus dynamics in response to dairy manure and inorganic fertilizer applications. Soil Science, v. 171, p. 598-609, 2006.

https://doi.org/10.1097/01.ss.0000228039.65023.20

HEDLEY, M. J., STEWART, J. W. B.; CHAUHAN, B. S. Changes in inorganic and organic soil phosphorus fractions induced by cultivation practices and by laboratory incubations. Soil Science Society of America Journal, v. 46, p. 970-976, 1982. https://doi.org/10.2136/sssaj1982.03615995004600050017x

HINSINGER, P. Bioavailability of soil inorganic $\mathrm{P}$ in the rhizosphere as affected by root-induced chemical changes: a review. Plant and Soil, v. 237, p. 173-195, 2001 https://doi.org/10.1023/A:1013351617532

HIRATA, H.; WATANABE, K.; FUKUSHIMA, K.; AOKI, M.; IMAMURA, R.; TAKAHASHI, M. Effect of continuous application of farmyard manure and inorganic fertilizer for 9 years on changes in phosphorus compounds in plow layer of an upland Andosol. Soil Science and Plant Nutrition, v. 45, p. 577-590, 1999. https://doi.org/10.1080/00380768.1999.10415821

HOSSEINPUR, A. R.; KIANI, S.; HALVAEI, M. Impact of municipal compost on soil phosphorus availability and mineral phosphorus fractions in some calcareous soils. Environmental Earth Sciences, v. 67, p. 91-96, 2012. https://doi.org/10.1007/s12665-011-1482-1

JALALI, M.; RANJBAR, F. Aging effects on phosphorus transformation rate and fractionation in some calcareous soils. Geoderma, v. 155, p. 101-106, 2010. https://doi.org/10.1016/j.geoderma.2009.11.030

KINGERY, W. L.; WOOD, C. W.; DELANEY, D. P.; WILLIAMS, J. C.; MULLINS, G. L. Impact of longterm land application of broiler litter on environmentally related soil properties. Journal of Environmental Quality, v. 23, p. 139-147, 1994. https://doi.org/10.2134/jeq1994.00472425002300010022x https://doi.org/10.2134/jeq1994.231139x 
KOOPMANS, G. F.; CHARDON, W. J.; DOLFING, J.; OENEMA, O.; VAN DER MEER, P.; RIEMSDŸK, W. H. Wet chemical and phosphorus-31 nuclear magnetic resonance analysis of phosphorus speciation in a sandy soil receiving long term fertilizer or animal manure applications. Journal of Environmental Quality, v. 32, p. 287-295, 2003. https://doi.org/10.2134/jeq2003.2870

MANDAL, M.; CHANDRAN, R.S.; BALASKO, J. Amending subsoil with composted poultry litter-II: Effects on Kentucky bluegrass (Poa pratensis L.) establishment, root growth, and weed populations. Agronomy, v. 3, p. 670-684, 2013. https://doi.org/10.3390/agronomy3040670

MAGUIRE, R.; PLUMSTEAD, P. W.; BRAKE, J. Impact of diet, moisture, location, and storage on soluble phosphorus in broiler breeder manure. Journal of Environmental Quality, v. 35, p. 858-865, 2006. https://doi.org/10.2134/jeq2005.0435

MALONE, G. W. Nutrient enrichment in integrated broiler production systems. Poultry Science, v. 7, p. 1117-1122, 1992. https://doi.org/10.3382/ps.0711117

MILLER, J. J.; BEASLEY, B. W.; DRURY, C. F.; ZEBARTH, B. J. Available nitrogen and phosphorus in soil amended with fresh or composted cattle manure containing straw or woodchip bedding. Canadian Journal of Soil Science, v. 90, p. 341-354, 2010. https://doi.org/10.4141/CJSS09053

MOZAFFARI, M.; SIMS, J. T. Phosphorus transformations in poultry litter amended soils of the Atlantic coastal plain. Journal of Environmental Quality, v. 25, p. 1357-1365, 1996.

https://doi.org/10.2134/jeq1996.2561357x

https://doi.org/10.2134/jeq1996.00472425002500060027x

NELSON, D. W.; SOMMERS, L. E. Organic carbon. In: Methods of Soil Analysis, Part 2, ASA, SSSA, Madison, WI, USA, p. 561-579, 1982.

OLSEN, S. R.; SOMMERS, L. E. Phosphorus. In Page, A.L., Miller, R. H. and Keeney, D.R. (eds). Methods of Soil Analysis. Part 2.2nd edn. Agronomy Series No. 9, American Society of Agronomy and Soil Science Society of America, Inc., Madison, WI, p. 403-430, 1982. https://doi.org/10.4141/cjss10026

OLSON, B. M.; MCKENZIE, R. H.; LARNEY, F. J.; BREMER, E. Nitrogen- and phosphorus-based applications of cattle manure and compost for irrigated cereal silage. Canadian Journal of Soil Science, v. 90, p. 619-635, 2010.

PRASAD, R.; POWER, J. F. Soil fertility management for sustainable agriculture. CRC Press LLC. Boca Raton, Florida, USA. 347, 2000.

RAO V. S. R. Litter- its management and utility in broiler. Poultry Adviser, v. 19 n. 7-12, p. 31- 40, 1986.

REDDY, K. R.; KADLEC, R. H.; FLAIG, E.; GALE, P. M. Phosphorus retention in streams and wetlands: A review. Critical Reviews in Environmental Science and Technology, v. 29, n. 1, p. 83-146, 1999. https://doi.org/10.1080/10643389991259182

ROBINSON, J. S.; SHARPLEY, A. N. Reactions in soils of phosphorus released from poultry litter. Soil Science Society of America Journal, v. 60, p. 1583-1588, 1996.

https://doi.org/10.2136/sssaj1996.03615995006000050043x

ROY, S.; KASHEM, M. Effects of Organic Manures in Changes of Some Soil Properties at Different Incubation Periods. Open Journal of Soil Science, v. 4, p. 81-86, 2014.

https://doi.org/10.4236/ojss.2014.43011 
SABIR, M.; GHAFOOR, A.; SAIFULLAH; REHMAN, M. Z.; MURTAZA, G. Effect of organic amendments and incubation time on extractability of $\mathrm{Ni}$ and other metals from contaminated soils. Pakistan Journal of Agricultural Science, v. 45, p. 18-24, 2008.

SANCHEZ, P. A.; UEHARA, G. Management considerations for acid soils with high phosphorus fixation capacity. In: F.E. Khasawneh et al. (ed.): The role of phosphorus in agriculture. ASA, CSSA, and SSSA, Madison, WI. P. 471-514, 1980.

SHARPLEY, A.; MOYER, B. Phosphorus forms in manure and compost and their release during simulated rainfall. Journal of Environmental Quality, v. 29, 1462-1469, 2000.

https://doi.org/10.2134/jeq2000.2951462x

https://doi.org/10.2134/jeq2000.00472425002900060056x

https://doi.org/10.2134/jeq2000.00472425002900050012x

SHARPLEY, A. N.; MOYER, B. Phosphorus forms in manure and compost and their release during simulated rainfall. Journal of Environmental Quality, v. 29, p. 1462-1469, 2000.

https://doi.org/10.2134/jeq2000.2951462x

https://doi.org/10.2134/jeq2000.00472425002900060056x

https://doi.org/10.2134/jeq2000.00472425002900050012x

SHARPLEY, A. N.; HERRON, S.; DANIEL, T. Overcoming the challenges of phosphorus-based management in poultry farming. Journal of Soil and Water Conservation, v. 58, p. 30-38, 2007.

SHEN, J., LI, R.; ZHANGA, F.; FAN, J.; TANG, C.; RENGEL, Z. Crop yields, soil fertility and phosphorus fractions in response to long-term fertilization under the rice monoculture system on a calcareous soil. Field Crops Research, v. 86, p. 225-238, 2004. https://doi.org/10.1016/j.fcr.2003.08.013

SIMS, J. T.; EDWARDS, A. C.; SCHOUMANS, O. F.; SIMARD, R. R. Integrating soil phosphorus testing into environmentally based agricultural practices. Journal of Environmental Quality, v. 29, p. 60-71, 2000. https://doi.org/10.2134/jeq2000.00472425002900010008x

https://doi.org/10.2134/jeq2000.29160x

SINAJ, S.; TRAORE, O.; FROSSARD, E. Effect of compost and soil properties on the availability of compost phosphate for white clover (Trifolium repens L.). Nutrient Cycling in Agroecosystems, v. 62, p. 89-102, 2002. https://doi.org/10.1023/A:1015128610158

SLATON, N. A.; WILSON JR, C. E.; NORMAN, R. J.; NTAMATUNGIRO, S.; FRIZZELL, D. L. Rice response to phosphorus fertilizer application rate and timing on alkaline soils in Arkansas, Agronomy Journal, v. 94, p. 1393-1399, 2002. https://doi.org/10.2134/agronj2002.1393

TANI, M.; MIZOTA, C.; YAGI, T.; FUEKI, N.; TAMUTA, H.; KATO, T.; KOIKE, M. Accumulated amount and formation of phosphate in cultivated upland low-humic Andisols through continuous application of inorganic fertilizers and cattle manure for 25 years. Journal of Soil Science and Plant Nutrition, v. 82, p. 231-234, 2011.

TOTH, J. D., DOU, Z., FERGUSON, J. D., GALLIGAN, D. T. AND RAMBERG, C. F. Nitrogen vs phosphorus based dairy manure applications to field crops: nitrate and phosphorus leaching and soil phosphorus accumulation. Journal of Environmental Quality, v. 35, p. 2305-2312, 2006.

https://doi.org/10.2134/jeq2005.0479

United States Department of Agriculture, Economic Research Service, Food Assistance and Nutrition Research Program, Competitive Grants and Cooperative Agreements Program: Description and Application Process Fiscal 2000, USDA, ERS, Mar. 2000. 
WANG, H. D.; HARRIS, W. G.; REDDY, K. R. Stability of phosphorus forms in dairy impacted soils under column leaching by synthetic rain. Ecological Engineering, v. 24, 324-329, 1995.

ZHENG, Z.; SIMARD, R. R.; LAFOND, J.; PARENT, L. E. Changes in phosphorus fractions of a Humic Gleysol as influenced by cropping systems and nutrient sources. Canadian Journal of Soil Science, v. 81, p. 175-183, 2001. https://doi.org/10.4141/S00-666

ZHU, N.; DENG, C.; XIONG, Y.; QIAN, H. Performance characteristics of three aeration systems in the swine manure composting. Bioresource Technology, v. 95, p. 319-326, 2004.

https://doi.org/10.1016/j.biortech.2004.02.021 